\title{
O ALEGORII JAKO WARUNKU ARCYDZIELNOŚCI EPICKIEJ
}

Słowa kluczowe: alegoria, poezja epicka, interpretacja alegoryczna

Keywords: allegory, epic poetry, allegorical interpretation

Jagnię tam chodzi, a dla stonia grzasko ${ }^{1}$

\section{1.}

We wprowadzeniu do poświęconego zagadnieniu alegorii tomu studiów, wydanego w 1994 roku w serii „Analecta Husserliana”, Anna Teresa Tymieniecka zauważyła, iż współcześnie, zarówno w sferze ekspresji artystycznej, jak i w szeroko pojętej przestrzeni kultury, alegoria zanikła jako forma wyrazu i można odnieść wrażenie, iż nie jest zdolna dłużej odpowiadać na żywe kulturowe potrzeby, tak indywidualne, jak i społeczne - wyjątkiem pozostają akty jej pragmatycznych, doraźnych zawłaszczeń w celu uwiarygodniania różnych, nierzadko utopijnych, ideologii ${ }^{2}$. Główną przyczynę tego stanu rzeczy - aktualnego dziś podobnie jak dwadzieścia lat wcześniej, gdy powyższa diagnoza została sformułowana - uczona wiąże z konsekwencjami intensywnego rozwoju nauk szczegółowych i postępu technicznego, wskutek czego - a można pokusić się tu o przyznanie racji jej ocenie - doszło do skanalizowania spekulatywnych funkcji ludzkiego umysłu w jednym, wyłącznie utylitarnym kierunku: odkrywania nowych technologii i opracowywania metod ich zastosowania ${ }^{3}$. W świetle tak rysujących się tendencji w obrębie współczesnych horyzontów myśli i potrzeb twórczych, tym wyraźniej zaznacza się odmienne wobec ich porządku ukierunkowanie struktur

\footnotetext{
${ }^{1}$ Konrad z Hirschau, „Dialog o autorach”, in Źródła do średniowiecznej teorii wykładu literatury, trans. Mieczysław Brożek (Warszawa: Państwowe Wydawnictwo Naukowe, 1989), 153.

${ }^{2}$ Cf. Anna Teresa Tymieniecka, „The Theme. Passions Soaring Toward Ideals: Allegory and the Ideals of Mankind", Analecta Husserliana, vol. 41 (1994): xi.

${ }^{3} \mathrm{Cf}$. ibidem, xiii.
} 
symbolicznych, których obrazowość i fabularność zyskuje swój zupełny kształt i ostateczne uzasadnienie w przenikającej je treści intelektualnej, wzywającej odbiorcę do jej odkrywania i poznawania. Alegoria oraz w ogóle cały figuralny porządek wyrażania, który - jak stwierdza A.T. Tymieniecka - ma kluczowe znaczenie dla doskonalenia ludzkiego ducha, dla komunikacji i rozszerzania jej zasięgu ${ }^{4}$, nie posiada ukierunkowania pragmatycznego ani w sensie ścisłym, ani nawet przenośnym. Bezpośrednio związana z władzami poznawczymi i zagadnieniem wyobraźni, alegoryczność wzmacnia łączenia między kontemplacyjnym i dyskursywnym poziomem aktywności kulturowej, integrując tym samym jej złożoną dynamikę.

Uprzywilejowaną pozycję nośnika treści kulturotwórczych mowa figuralna zawdzięcza swojej naturze obrazowo-abstrakcyjnej, łączącej jakości zmysłowe i intelektualne, co czyni ją już u podstaw tropem na wskroś antropologicznym, odwzorowującym ludzką złożoność cielesno-duchową. Jej siła atrakcyjna wiąże się też z charakterystyczną perswazyjną dyskrecją otaczającą sensy ukryte w strukturze symbolicznego obrazu, sceny czy fabuły. Pośredni przekaz nie narzuca się uwadze, lecz niejako trwa w gotowości bycia rozpoznanym i przyjętym przez odbiorcę - szczególnie takiego, którego intuicja hermeneutyczna została wyostrzona dzięki interioryzacji sugerowanych przez alegoryczną imago treści, uznawanych niekiedy (zwłaszcza w dawniejszej krytyce) za abstrakt możliwy do przyporządkowania do obrazu jedynie na sposób konwencjonalny i dogmatyczny ${ }^{5}$.

Naturalna tendencja do idealizacji i alegoryzacji wyłania się z gotowości przyjmowania pełnego zakresu ludzkiego doświadczenia - dzieje się tak wówczas, gdy aktywność intelektualna nie jest redukowana do służby doraźnej praxis, lecz może w pełni rozwijać się w podporządkowaniu jedynie prawom twórczej logiki i wyobraźni; gdy intelekt staje się architektem własnych pomysłów czerpanych z doświadczeń zmysłowych i afektywnych, prześwietlanych przez specyficznie ludzką zdolność odkrywania w nich wymiaru estetycznego, moralnego czy religijnego ${ }^{6}$.

Jakkolwiek tendencja do alegoryzacji ma charakter naturalny, będąc rezultatem spekulatywnych władz umysłu współdziałających z imaginacyjnym ingenium, to jednak percepcja znaczeń alegorycznych nie rozwija się w procesie lektury

\footnotetext{
${ }^{4}$ Cf. ibidem, xiv.

${ }^{5}$ Cf. przedstawione przez H.-G. Gadamera podsumowanie XVIII- i XIX-wiecznej krytyki alegoryzmu, inspirowanej wpływem rozwijających się subiektywistycznych tendencji w estetyce. Vide Hans-Georg Gadamer, Prawda i metoda. Zarys hermeneutyki filozoficznej, trans. Bogdan Baran (Warszawa: Wydawnictwo Naukowe PWN, 2004), 122. Problem ten poruszam też w mojej książce. Vide Agnieszka Czechowicz, „Wszytko to pod figura”. Studia o miejscu alegorii w poematach heroicznych XVII wieku (Lublin: Wydawnictwo KUL, 2015), 29-44. O kwestii traktowania obrazu alegorycznego na wzór znaku językowego, a więc jako arbitralnego i konwencjonalnego, graficznego unaocznienia abstrakcyjnej treści myślowej - vide Elżbieta Wolicka, „O różnych typach wyobraźni symbolicznej”, Zwrot, no. 2(3) (1988): 54.

${ }^{6}$ Cf. Anna Teresa Tymieniecka, Analecta Husserliana, xiii.
} 
dzieła literackiego zupełnie samorzutnie, tak jak samorzutnie wraz z lekturą epickiej fabuły w wyobraźni czytelnika kształtuje się odbicie świata przedstawionego i narasta jego pojmowanie, które za Romanem Ingardenem nazywamy konkretyzacją. Obraz alegoryczny ma charakter wyobrażeniowo-abstrakcyjny. Jest podobieństwem, w którym to, co postrzegają zmysły, odnajduje harmonię z tym, co poznaje się myślą. Rozpięty jest między sferą zjawisk, wrażeń, emocji oraz intersubiektywnych doświadczeń a tą dziedziną refleksji intelektualnej, która jest owocem pielęgnowania przenikających kulturę dążeń transcendentnych ${ }^{7}$. Obok sprzyjającej hermeneutyce figuralnej interioryzacji treści moralnych czy religijnych, potrzeba więc pewnej intelektualnej praktyki - można by ją nazwać nawykiem myślenia analogicznego - by z imaginacyjnej naoczności uwolnić znaczenia przenośne czy też, innymi słowy, dostrzec w niej ich obecność.

Alegoryzacja refleksji, skłonność do ekspresji nie wprost, ale „przez zwierciadło", a więc przez szeregi podobieństw, o których wyborze zdają się rozstrzygać uprzednie pogłębione analizy dyskursywnej pojemności obrazowych form, mających unieść wpisane w nie treści, związana jest też z pojawiającą się niekiedy potrzebą szeroko pojętej ochrony przekazu. Oczywiście nie musi tu wcale chodzić o rzeczy tak podstawowe, jak ustrzeżenie idei wywrotowych przed opresja ze strony instytucji władzy albo zabezpieczenie prawd ważkich i świętych przed sprofanowaniem przez niewtajemniczonych. Idzie tu raczej o wspomnianą wyżej dyskrecję stosowną dla „treści głębokich”, związanych z rzeczywistością doświadczenia wewnętrznego, lub też układających się we wzorzec idei moralnych lub religijnych. Ochronna funkcja alegorycznych figur bliska jest poniekąd delikatnym zadaniom spełnianym przez (nieodległą skądinąd od ostentacji) topikę egzordialną, która zjednywać ma mówcy/autorowi przychylność audytorium i oddalać od niego możliwe zarzuty pychy lub też domniemania nietrafnej (bo zaniżonej) oceny intelektualnych kompetencji jego słuchaczy.

Prawdy o szczególnym znaczeniu tradycja retoryczna zalecała - przede wszystkim w poezji - wypowiadać godnie i ozdobnie, pod różnymi osłonami, tak by nie wystawiać ich przed oczy tych, którzy wprawdzie bywają ciekawi, lecz sami niechętni są temu, by podjąc trud rozumienia rzeczy przedstawianych nie wprost ${ }^{8}$.

\footnotetext{
${ }^{7}$ Cf. ibidem, XIV-XV. Moje obserwacje są tu w pewnym stopniu paralelne wobec (prowadzonej z pozycji fenomenologicznych) syntetycznej refleksji Anny Teresy Tymienieckiej, zamieszczonej w przywołanym wyżej wstępie do „alegorycznego” tomu Analecta Husserliana.

${ }^{8}$ Piękną pochwałę „niejasności” poetów znajdujemy u Boccaccia - rzecznika „czystej poezji” układanej pod osłoną; vide Giovanni Boccaccio, „O pochodzeniu bogów pogańskich”, trans. Grzegorz Błachowicz, in Źródta wiedzy teoretycznoliterackiej w dawnej Polsce. Średniowiecze - Renesans - Barok, ed. Maria Cytowska et Teresa Michałowska (Warszawa: Wydawnictwo Naukowe PWN, 1999), 187-192. O średniowiecznej tradycji retorycznej ornatus difficilis i o transumpcji jako głównym narzędziu trudnej ozdobności vide Teresa Michałowska, Literatura polskiego średniowiecza wobec poetyki europejskiej (,ornatus difficilis”) (Warszawa: Instytut Badań Literackich PAN et Fundacja Akademia Humanistyczna, 2008), 46-72.
} 
Pośrednictwo alegoryczne ma więc wielofunkcyjną naturę. Posiada walor estetyczny, epistemologiczny, ale także etyczny, pozwala bowiem zminimalizować ryzyko, że prawda, obnażona a nieprzyjęta, zostanie porzucona jako niewiążąca moralnie. Trudno nie uznać intuicyjnej przenikliwości starych porównań alegorii do szaty, która ochrania, a jednocześnie przystraja i strzeże dostojeństwa osłoniętego nią ciała. Tym właśnie obrazem, jako argumentem w swojej obronie poezji, posłużył się Petrarka, zadanie poety opisując jako „ozdabianie rzeczywistości pięknym strojem, aby była nie do poznania dla pozbawionego smaku tłumu" 9 .

Przeciwieństwem vulgus insulsum z Inwektywy przeciwko medykowi Petrarki mają być lectores ingeniosi atque studiosi - uzdolnieni i gorliwi czytelnicy, umiejący czerpać przyjemność z odkrywania prawdy przysłoniętej fikcyjnymi obra$z{ }^{10}{ }^{10}$. W tej wyrazistej retorycznie alternatywie, w której autor Afryki ukazał dwie przeciwstawne postawy wobec poezji - arogancką wzgardę i pełen pietyzmu zapał - znika sprzed oczu nastawienie trzecie, jakie żywią wobec tej sztuki odbiorcy ceniący ją sobie o tyle, o ile dostarcza im ona pożądanej, godziwej rozrywki. A więc pochłania uwagę, cieszy, porusza, zdumiewa. Źródłem przyjemności w poezji jest, będące jej „celem bliższym”, naśladowanie, a zatem - w przypadku epiki heroicznej, ona jest bowiem wzorcem i źródłem wszystkich innych gatunków poetyckich ${ }^{11}$ - rozwijanie przed oczami wyobraźni czytelnika historii, wybranej jako temat poetyckiego opowiadania, oraz doprowadzenie jej do szczęśliwego zakończenia, właściwego kreacji epickiej. Poruszająca emocje fikcja, czyli obrazowość i fabularność poetycka, żywość swojego oddziaływania zawdzięcza, obok stylistycznej, przede wszystkim właśnie naśladowczej sprawności poety i żeby się nią cieszyć, nie potrzeba przecież szczególnych talentów, pilności czy zapału - wystarczy naturalna skłonność ludzka do tego, by - jak pisał św. Tomasz z Akwinu - mile przyjmować wszelkie obrazowania ${ }^{12}$.

„Czytelnik średni”, mający taką niewyrafinowaną czy wręcz „konsumencką” dyspozycję lekturową, nieszukający satysfakcji w odkrywaniu sensu alegorycznego, lecz oddany w czytaniu prostej przyjemności mimetycznej i fabularnej, skupiony na rozwoju epickiej akcji i przeżywający „burzący się w zdaniach gniew i ból”, nie jest więc wykluczony jako potencjalny odbiorca dzieła, które cenne prawdy i myśl utajoną skrywa w materii pociągającej fikcji. Sama bowiem możliwość

${ }^{9}$ Francesco Petrarca, „Inwektywy przeciw medykowi”, trans. Cyprian Mielczarski, in Źródta wiedzy teoretycznoliterackiej $w$ dawnej Polsce, 183.

${ }^{10} \mathrm{Cf}$. ibidem.

${ }^{11}$ Tak ujmuje ją choćby Juliusz Cezar Scaliger; vide Julius Caesar Scaliger, „Poetyka”, trans. Jerzy Mańkowski, in Poetyka okresu renesansu. Antologia, ed. Elżbieta Sarnowska-Temeriusz (Wrocław: Zakład Narodowy im. Ossolińskich, 1982), 274-275.

${ }^{12}$ Cf. św. Tomasz z Akwinu, Suma teologiczna, vol. 1, trans. Pius Bełch (London: Katolicki Ośrodek Wydawniczy Veritas, 1975), 72 (Q I, art. 9). 
czerpania radości z poezji nie jest w pierwszym rzędzie pochodną wysiłku i starań czytającego, jako że ten spełnił już minimum wymagań w tym względzie samą swoją gotowością szukania wytchnienia i przyjemności właśnie w dziełach literackich, a to już z zasady wyłącza go z niewrażliwego na poetycką słodycz „pozbawionego smaku tłumu". Tutaj powodzenie w odbiorze - upodobanie w dziele i uznanie dla jego wartości - uzależnione jest od kunsztu samego autora.

W długiej historii literatury mamy liczne przykłady dzieł, które „zaprzątają umysły najgenialniejszych czytelników i doktorów”, a zarazem „odpowiadają również młodym i mniej pojętnym umysłom" - jak Konrad z Hirschau opisywał specyfikę Boecjuszowej De consolatione philosophiae ${ }^{13}$. Dzieła, o których mowa, atrakcyjne są zarówno dla odbiorców wyćwiczonych, ogarniających uwagą wszystkie warstwy utworu oraz poziomy znaczeń, jak i dla czytelników o mniej zaawansowanych kompetencjach lekturowych, którzy w poezji szukają odpoczynku od trudów życia i jego powagi bądź też sięgają do nich tylko po wzory stylistyczne. Na kartach takich dzieł nie piętrzą się przeszkody zakłócające niezobowiązującą lekturę przyjemnościową (bądź szkolną), a mimo to odbiorcy żarliwi i pilni wyczuwają w ich obrazach i epizodach intelektualny ruch w kierunku treści, które energii mimetycznego oddziaływania przydają trwałości i powagi uniwersalnej. Taka jest specyfika arcydzieł i Konrad z Hirschau zamknął ją w obrazowej analogii, ukazującej harmonijne współistnienie (właśnie w arcydziele) atrakcyjnej dla wszystkich mimesis z ukrytą mądrością, czekającą na odkrycie przez zaawansowanych: „dzielny pod brzemieniem się poci, a słaby pod ciężarem nie ugina karku, jak mówi ludowe przysłowie: Jagnię tam chodzi, a dla słonia grząsko"14. W podobny sposób, powołując się na Plutarcha, pisał Maciej Kazimierz Sarbiewski: „Taka jest natura poezji i taki zwyczaj dawnych pisarzy, iż pewne rzeczy podają w sposób zagadkowy i pod postacią mitu, aby ci, którzy naprawdę pragną się czegoś nauczyć, znęceni subtelnościami wykładu, tym łatwiej szukali prawdy i znajdowali ją, a ludzie nieuczeni nie pogardzali tym, czego pojąć nie mogą"15.

2.

O tym, jak kultura wczesnonowożytna pojmowała epicką arcydzielność, świadczą między innymi uwagi, jakie poczynił John Bill, drukarz Jakuba I Stuarta, przypisując drugie angielskie wydanie Jerozolimy wyzwolonej Tassa (nazwanego tam chrześcijańskim Homerem) przyszłemu monarsze Karolowi I. Królewski impresor pisał w swej dedykacji, że poemat jest wart czytania nie tylko

${ }^{13}$ Cf. Konrad z Hirschau, „Dialog o autorach”, 153.

${ }^{14}$ Cf. ibidem.

${ }^{15}$ Maciej Kazimierz Sarbiewski, O poezji doskonatej, czyli Wergiliusz i Homer (De perfecta poesi, sive Vergilius et Homerus), trans. Marian Plezia, ed. Stanisław Skimina (Wrocław: Zakład im. Ossolińskich et Wydawnictwo PAN, 1954), 188-189. 
ze względu na historię, której powagę uznają wszyscy chrześcijanie, oraz na wizerunek sławy wielu bohaterów. Kunszt twórcy - pisał John Bill - jest tu godzien podziwu zarazem przez zalety naśladowania poetyckiego, jak i z uwagi na alegorię. Dzieło Tassa nie zawiera w sobie wyłącznie prawdy historycznej, osłodzonej poetyckimi zmyśleniami, ale w tajemniczy sposób wyraża także sensy moralne; ukazuje bowiem praktyczny wymiar cnoty prowadzącej ku najwyższej szczęśliwości, dzięki czemu w tym samym czasie rozum może poznawać historię, wyobraźnia - rozkoszować się poetyckimi ozdobami, a wola - zyskiwać prawidłowe ukierunkowanie przez przykłady moralne ${ }^{16}$. Angielski wydawca zaznacza, że ku takim celom kierowały się oczywiście także i inne poematy epickie, lecz w żadnym przed Tassową Jerozolima nie zostały osiągnięte z takim powodzeniem.

Czytelnik - o czym dobrze wiedział drukarz John Bill - na ogół dysponuje zdolnością odczytywania wielopoziomowego. Podąża za tokiem narracji w jego rozwoju chronologicznym, a lekturze tej towarzyszy synchroniczna praca intelektu, konstruującego scalony wizerunek ludzkich czynów i losów ${ }^{17}$. Dzieło heroiczne spełnia się jako całość, w obu składających się na jego wymowę wymiarach, dopiero wówczas, gdy wywołuje w czytelniku niejako stereofoniczny rezonans ${ }^{18}$. O alegorycznym wymiarze opowieści epickiej nie możemy powiedzieć, że jest on dyskursywnym ekwiwalentem samej opowieści. Dyskursywność nie jest bowiem równoważnikiem mimesis, lecz jej wewnętrznym, ożywiającym źródłem, tak jak ukryta w głębi ogrodu sadzawka, która ożywia zasadzone wokół niej rośliny, utrzymuje je przy życiu i umożliwia ich kwitnienie.

Odsłanianie alegorycznego wymiaru poematu epickiego nie musi dokonywać się w sposób metodyczny. Nie znaczy to jednak, że na tym właśnie poziomie odczytania proces hermeneutyczny nie jest poddany regułom ekonomii asocjacyjnej, kryterium wewnętrznej spójności czy niesprzeczności znaczeń jednej części dzieła wobec innych i, ostatecznie, wobec jego całości ${ }^{19}$. Przenośna lektura nie ma charakteru dowolnego. Jej logika zakorzeniona jest w wiarygodności mimesis dzieła, w którym im więcej życia, tym większa podatność na alegoryczne interpretacje ${ }^{20}$.

${ }^{16}$ Cf. John Bill, „To the Most Illustrious and Most Excellent Prince Charles [...]”, in Torquato Tasso, Godfrey of Boulogne or the Recouerie of Jerusalem. Done into English Heroicall Verse by Edward Fairefax Gent [...] (London: John Bill, 1624), 3r-3v.

${ }^{17}$ Cf. Brian Vickers, „Epideictic and Epic in the Renaissance”, New Literary History, vol. 14, no. 3 (1983): 528-529.

${ }^{18} \mathrm{~W}$ podobny sposób postrzega poetycką alegorię Edward A. Bloom. Vide Edward A. Bloom, „The Allegorical Principle”, ELH, vol. 18, no. 3 (1951): 164-165.

${ }^{19} \mathrm{O}$ podobnych kryteriach interpretacyjnych pisał Umberto Eco w eseju „Nadinterpretowanie tekstów", in Umberto Eco et al., Interpretacja i nadinterpretacja, ed. Stefan Collini, trans. Tomasz Bieroń (Kraków: Wydawnictwo Znak, 1996), 45-65.

${ }^{20}$ Cf. John Ronald Reuel Tolkien, The Letters, ed. Humphrey Carpenter, Christopher Tolkien (Boston: Houghton Mifflin Company, 1981), 145 (list do Miltona Waldmana). 
Określenie „symbolizm alegoryczny”21 wydaje się dla mechanizmu znaczeń poezji epickiej najtrafniejsze, jeżeli będziemy pamiętać, że jego związki z mimetyzmem są głębsze niż z retoryką.

Relację rekonstrukcji treści mądrościowych eposu do jego odbioru literalnego (mimetycznego, fabularnego) można opisać podobnie, jak uczynił to Dante w drugim traktacie swego Convivium:

I w takim objaśnieniu - pisał autor Boskiej komedii o alegorycznej eksplikacji kancon otwierających kolejne traktaty Biesiady - zawsze dosłowne znaczenie powinno iść przodem jako to, w którego znaczeniu zamknięte są pozostałe i bez którego niemożliwe i nielogiczne byłoby zrozumienie pozostałych, w szczególności zaś alegorycznego. Jest to niemożliwe, bowiem w przypadku każdej rzeczy, która ma wnętrze i zewnętrze, niemożliwe jest dotarcie do wnętrza, jeśli wprzódy nie dotrze się na zewnątrz [...]. Niemożliwe to jest również dlatego, że w każdej rzeczy, naturalnej czy też sztucznej, nie można przejść do formy, gdy nie został przygotowany przedmiot, na który ma być nałożona forma: jak nie może być urzeczywistnioną forma złota jeśli materia, a więc rzecz jej poddana, nie została przysposobiona i przygotowana; ani forma skrzyni nie może się spełnić, gdy materia, czyli drewno, nie jest uprzednio przysposobione i przygotowane. Stąd ponieważ dosłowne znaczenie zawsze jest podstawą i materią innych sensów, zwłaszcza zaś alegorycznego, nie można poznać tamtych przed tym. Niemożliwe jest to też i dlatego, że w żadnej rzeczy, prawdziwej czy też sztucznej, nie można robić postępów, jeśli pierwej nie położono fundamentów, czy to w przypadku domu, czy też nauki $[\ldots]$.

Więcej jeszcze, choćby przyjąć, że jest możliwe, byłoby to nielogiczne, to znaczy poza porządkiem, i dlatego brnęłoby się naprzód $\mathrm{z}$ wielkim trudem i wielkim błądzeniem ${ }^{22}$.

Trudy i błądzenie w lekturze nie byłyby w opisywanym przez Dantego przypadku konsekwencją ornatus difficilis, lecz wynikiem wad poematu. Będąc z natury obce poezji, oddalałyby ją od jej celu, jakim jest dające radość i wytchnienie zespolenie mądrości i piękna, znane od czasów Horacjańskich w formule utile dulci miscere, przyjętej w zasadzie przez aklamację przez główny nurt wczesnonowożytnych rozważań o ars poetica. Dulcitas - przynajmniej z pozoru - niełatwo uzgodnić z trudem. Tasso, pisząc o sonecie, przeciwstawiał wysiłek, od którego stroni natura ludzka, przyjemności, ku której się skłania:

[...] poeta musi dawać przyjemność, czy to dlatego, że, jak ja sądzę, przyjemność jest jego celem, czy że jest niezbędnym środkiem do niesienia pożytku, jak sądzą inni, to nie jest dobrym poetą ten, który nie sprawia przyjemności, a nie może jej sprawiać pojęciami, które są trudne i ciemne: człowiek bowiem musi wysilać umysł, aby je zrozumieć, a ponieważ trud nie daje się pogodzić z ludzką naturą i przyjemnością, to nigdzie, gdzie on jest, nie może być przyjemności ${ }^{25}$.

${ }^{21}$ Posługuje się nim Elżbieta Wolicka, op. cit., 56.

${ }^{22}$ Dante Alighieri, Biesiada, trans. et ed. Magdalena Bartkowiak-Lerch (Kęty: Wydawnictwo Antyk, 2004), 44.

${ }^{23}$ Torquato Tasso, „Lezione sopra un Sonetto di M. della Casa”, in Władysław Tatarkiewicz, Historia estetyki, vol. 3 (Warszawa: Wydawnictwo Arkady, 1991), 184. 
Kwestia relacji między słodyczą i trudem w poezji nie dla wszystkich wczesnonowożytnych twórców była wszakże tak jednoznaczna, jak przedstawił ją tutaj, nastawiony do trudów pesymistycznie, autor Jerozolimy wyzwolonej. Maciej Kazimierz Sarbiewski widział w poezji najszlachetniejszą ze wszystkich sztuk, a przez to też i sztukę najtrudniejszą, będącą, jak powtarzał za Platońskim Fajdrosem, dziełem dusz nie tylko uległych nadprzyrodzonym impulsom, ale i nieustraszonych, a więc właśnie tych, które nie dają się zrazić trudnościom ${ }^{24}$. Mimesis dzieła - jak przekonywali m.in. Sarbiewski czy Girolamo Fracastoro - jest w ostatecznym rachunku naśladowaniem raczej idei niż rzeczy w ich zmysłowych kształtach, a to już w samym akcie twórczym wymaga swoistego przedzierania się od tego, co proste w swej naoczności ku temu, co duchowe, więc nieoczywiste. Dzięki tej naturze poezja zyskuje wymiar uniwersalności, ukazuje to, co w rzeczach istotne i, stając się formą piękna, realizuje określony obraz w jego właściwej postaci ${ }^{25}$.

Poematy heroiczne najwyższej próby, takie jak Jerozolima wyzwolona Tassa, także można porównać do ogrodów, które jedni odwiedzają i cieszą się kwiatami, a inni wchodzą głębiej, by zabrać ze sobą również owoce. Według Alegorii poematu, którą Tasso postanowił dołączyć do swego dzieła, a którą zbyt skrupulatnie zwykło się pomijać w jego interpretacji ${ }^{26}$, Jerozolima ukazuje - tak jak wykłada to jej autor - uwieńczony zwycięstwem wysiłek osobowej integracji wewnętrznej, dzięki któremu, wskutek poddania niższych władz duszy zwierzchności rozumu, człowiek osiąga wolność umożliwiającą mu pełen udział w godziwej szczęśliwości życia doczesnego, obywatelskiego, społecznego (które Tasso nazywa la felicità civile albo la felicità politica), i, w konsekwencji, staje się też gotowy do tego, by uczestniczyć w dobrach życia nieśmiertelnego ${ }^{27}$. Na pytanie jednak,

${ }^{24}$ Cf. Maciej Kazimierz Sarbiewski, O poezji doskonałej, 191.

${ }^{25}$ Cf. Alicja Kuczyńska, Człowiek $i$ świat. Watki antropologiczne w poetykach renesansu wtoskiego (Warszawa: Państwowe Wydawnictwo Naukowe, 1976), 108.

${ }^{26} \mathrm{~W}$ polskiej literaturze przedmiotu Alegoria Tassa albo pozostaje zupełnie przemilczana, albo stosunek do niej wyznacza wciąż opinia Romana Pollaka wyrażona w jego wstępie do edycji poematu: „Oczywiście była to bardzo sztuczna alegoria ex post, tj. sklecona już po napisaniu i wydaniu dzieła. [...] Tę alegorię dołączano do wielu późniejszych wydań Jerozolimy, które przechodziły przez kościelną cenzurę. Ale i sam Tasso nie mógł w nią uwierzyć [...]”. Roman Pollak, „Wstęp”, in Torkwato Tasso, Gofred abo Jeruzalem wyzwolona, trans. Piotr Kochanowski, ed. Roman Pollak (Wrocław: Zakład Narodowy im. Ossolińskich, 1951), XXI-XXII. Wszystkie cytaty z Jerozolimy wyzwolonej w niniejszym artykule pochodzić będą z tego wydania. W badaniach obcojęzycznych obserwuje się dużo większe zróżnicowanie poglądów na temat alegorycznego potencjału Jerozolimy - od podważania istotnych relacji między dziełem i Alegorią do twórczych kontynuacji egzegetycznych wskazań poety. Jako przykład tego ostatniego typu można wskazać inspirowaną komentarzem Tassa interpretację znaczeń poematu w kluczu potrydenckiej nauki o sakramentach, vide Walter Stephens, „Metaphor, Sacrament, and the Problem of Allegory in «Gerusalemme Liberata»", I Tatti Studies in the Italian Renaissance, no. 4 (1991), 217-247.

${ }^{27}$ Cf. Torquato Tasso, „Allegoria del poema”, in idem, La Gerusalemme liberata, vol. 1 (Firenze: Presso Leonardo Ciardetti, 1823), XXVII-XXXVIII. 
czy inwencja Jerozolimy jest alegoryczna czy epicka, bez wahania odpowiedzieć trzeba, że w żadnym razie nie jest alegoryczna. Jerozolima różni się na polu inwencyjnym zasadniczo od takich dzieł jak Boska komedia, The Faerie Queene czy The Pilgrim's Progress, a poeta układający w pieśniach opowieść o zwycięstwie wyprawy krzyżowej jest epikiem, nie zaś twórcą romansowo-batalistycznej ilustracji do rozważań etycznych o życiu szczęśliwym czy o relacjach łączących vita activa i vita contemplativa.

Jerozolima jest więc rzeczywiście ułożoną w słowach żywych i skutecznych heroiczną powieścią o czynach rycerzy chrześcijańskich, którzy wyzwolili Grób święty spod władzy pogan. Celem tej opowieści jest - jak o imitacji epickiej pisał Tasso w swojej Alegorii - „pociągać umysły i uszy ludzi, i w sposób cudowny ich zachwycać” ${ }^{28}$, a więc - jak podkreślał na innym miejscu - „poruszać dusze czymś wprawiającym w podziw" ${ }^{29}$. To upodobanie, do którego poeta przywiązuje dużą wagę w swoich pismach, budzą w czytelniku: rozmaitość i nowość fabuły, zmienność i dynamika wydarzeń, moralna hojność protagonistów, w końcu zaś szczęśliwe ukończenie (wbrew nierzadko nadprzyrodzonym przeciwnościom i przy udziale nadprzyrodzonej pomocy) znakomitego przedsięwzięcia, którego waga przewyższa wszelkie doraźne korzyści i interesy każdego z poszczególnych, zaangażowanych w nie bohaterów. Źródłem „przyjemności epickiej” jest zatem szeroko pojęty plan mimetyczny.

W planie tym im mniej armia krzyżowa przypomina „dojrzałego człowieka złożonego z ciała i duszy, w której wyróżnić można wiele różnych władz" ${ }^{30}$, tym lepiej. Mamy ją tu bowiem rozpoznawać jedynie w takim kształcie, w jakim ,jasno ukazuje się naszym cielesnym oczom"31, to znaczy jako zwołanie oddziałów dzielnych rycerzy, reprezentujących narody europejskiej christianitas. Jerozolima nie powinna wyglądać jak „szczęście życia społecznego" - a więc, jak czytamy w Alegorii poematu - dobro trudne do osiągnięcia, znajdujące się na szczycie stromej i trudno dostępnej góry cnoty, ku któremu, jako ku ostatecznemu kresowi, kierują się wszelkie działania „człowieka politycznego"32, ale ukazywać się ma oczom wyobraźni po prostu jako miasto Grobu Bożego, który wojska Gofredowe przybyły wyzwolić spod władzy wyznawców Mahometa. Samego Gofreda, centralną postać poematu, czytelnik poznaje jako roztropnego i mężnego wodza świętej wyprawy, nie zaś jako personifikację rozumu praktycznego; Tankred i Rynald, z których jednym najsilniej powoduje miłość, a drugim dzielność, to dwaj najznamienitsi i najbarwniejsi krzyżowi rycerze a nie ucieleśnienia

\footnotetext{
${ }^{28}$ Ibidem, XXVII.

${ }^{29}$ Torquato Tasso, „Traktat o poemacie heroicznym”, trans. Teresa Dobrzyńska, in Poetyka okresu renesansu, 454.

${ }^{30}$ Idem, „Allegoria del poema”, XXX.

${ }^{31}$ Cf. ibidem, XXVII-XXVIII.

${ }^{32}$ Cf. ibidem, XXX.
} 
niższych władz duszy - pożądawczej i gniewliwej. I tak dalej - w podobny sposób można opisać wszystkich bohaterów i wszystkie elementy fabuły Tassowego poematu, oddzielając fabularną naoczność od jej potencjału alegorycznego, którego zasadnicze zręby wyłożył poeta w swoim komentarzu. Taka separacja nie zmieni jednak faktu, że wymienione (i wszystkie pozostałe) egzegetyczne detale autorskiej Alegorii swoje umocowanie w mimesis Jerozolimy zawdzięczają samej istocie poematu epickiego. Jest on - jak zgodnie podają klasyczne definicje - naśladowczym przedstawieniem a k cj i bohaterskiej, a więc ukierunkowanych na jeden cel czynów ludzkich. Czyny zaś, jako akty naznaczone pieczęcią osobową, poświadczają dyspozycję moralną ich wykonawcy i wyrażają na zewnątrz to, co Tasso określa jako namiętności, konflikty duchowe czy charakter $^{33}$. Zatem naoczność walki, ucieczki, błądzenia i poszukiwania, powrotu, zwycięstwa czy porażki, poza bezpośrednim wymiarem pragmatycznym, czyli wpływem na rozwój wydarzeń, reprezentuje też to, co niewidzialne, dzięki czemu fabularna dynamika akcji zaczyna jawić się jako analogiczna wobec moralnej dramaturgii rzeczywistych ludzkich aktów i doświadczeń, które na zewnątrz w niczym nie przypominają scen batalistycznych, rozstań, wspinaczek, pogoni czy leśnych strachów.

Znana scena nocnego pojedynku Tankreda i Kloryndy z XII pieśni poematu osadza się w pamięci czytającego jako wizerunek gorączki ludzkiego pragnienia, które ściga zaciekle rzecz postrzeżoną ad hoc jako wartą osiągnięcia (triumf nad wrogiem), lecz w rzeczywistości nie jest kierowane żadnym rozeznaniem. „O ludzkie myśli, głupie to czynicie, / że się za lada szczęściem unosicie!” (XII 58, w. 7-8) - słyszymy głos narratora komentującego dumę i radość Tankreda, który na widok ran, jakie zadał nierozpoznanej Kloryndzie, spodziewa się rychłej śmierci swego przeciwnika. W ciemnościach, pozbawiony możliwości wyjrzenia choćby na jeden krok poza doraźność, bez jakiegokolwiek wglądu w możliwe konsekwencje realizacji obranego celu, człowiek zostaje wydany na szyderstwo losu. Ślepe dążenie do osiągnięcia upragnionej korzyści okazało się pogonią za własną klęską. Szyderstwo jednak w końcu samo okazuje się pozorem - po krótkiej chwili zamienia się w łaskę, w szczęśliwe odwrócenie katastrofy. W głębi ukrytego planu, według którego toczą się ludzkie losy i w myśl którego splatają się ze sobą w przedziwne wzory, przewidziane zostaje nagłe odsłonięcie nieprzeczuwanej perspektywy, w której chaos doświadczenia zyskuje uzasadnienie, właściwy kształt i niechybną trafność:

Toś mi ty wszystko z łaski swojej sprawił,

Z świata mię tego omyłką zgładziwszy,

I u Boga-ś mię na łonie postawił,

Godną mię nieba przez krzest uczyniwszy.

${ }^{33}$ Cf. ibidem, XXVIII. 
Tyś mię wiecznego żywota nabawił,

Lecz i ty - ciało śmiertelne złożywszy -

Masz tu mieć miejsce, gdzie w wiecznej światłości

Cieszyć się będziesz z twej i z mej piękności.

(XII 92)

Tragiczny, a zarazem sakralny finał wielkiej miłości Tankreda jest oczywiście poruszający i zdumiewający - tak jak życzył sobie tego poeta - i bez sensów naddanych. Do tego, by dzieło heroiczne oddziaływało na czytających przez właściwą sobie przyjemność, jaką jest wprawianie w zdumienie i podziw, wystarczy - jak pisał Tasso w Rozważaniach o sztuce poetyckiej - wybór tematu zdolnego do przyjęcia najdoskonalszej formy artystycznej, ukształtowanie go według tej formy i przydanie mu stosownych do jego natury ozdób ${ }^{34}$. Świat przedstawiony opowieści heroicznej - a więc jej mimesis, dla której formę stanowi fabuła epicka - nie jest bowiem niewystarczalny i niesamoistny. Jego zaistnienie jako całości znaczącej nie wymaga uzasadnienia na płaszczyźnie idei, prawd wiary, kwestii moralnych czy koncepcji filozoficznych, tak jak dzieje się to w przypadku świata przedstawionego utworów alegorycznych, zbudowanych $\mathrm{z}$ fabuł intelektualnych, które od epickich różni zasadniczo natura fabularnej inwencji: nie mimetyczna jak w heroikach, ale translacyjna, przekładająca kategorie myślowe, wiązania logiczne oraz pojęcia na język obrazów, epizodów akcji i sekwencji fikcyjnych wydarzeń. Jednak interpretacja integralna, która uzgadnia zmysłowe piękno rzeczy z intelektualnym doświadczeniem ładu świata, uniwersalizuje mimesis dzieła i całą jej artystyczną zupełność otwiera na perspektywę poznawczą i etyczną. „Tu - jak pisał Władysław Tatarkiewicz - przestaje być obojętne - jak w przypadku symfonii barw czy dźwięków - czy to sen czy jawa, wizja czy rzeczywistość: myśląc chcemy zrozumieć nie fikcje i wizje, lecz realne życie, które widzimy" 35 .

Od struktury fabuły czy poszczególnych wątków epickich trudno oczekiwać, by w szczegółach ukazywały (choć przenośnie) „postępy każdego człowieka na drodze do prawdziwej mądrości”, jak o podróży Eneasza do Italii pisał Maciej Kazimierz Sarbiewski ${ }^{36}$. Obrazy poetyckie mają naturę podobieństwa (imago) nie zaś porównania (similitudo). Istotę odrębności między tymi dwoma typami figuralnymi Sarbiewski dostrzegał w różnicy stosunku wzajemnej odpowiedniości, jaka zachodzi między członami konstrukcji w jednej i w drugiej figurze. Podczas gdy w porównaniu „odpowiadają sobie wszystkie człony i istnieje oczywisty powód wytłumaczony treścią, dlaczego uważa się jeden człon za podobny

${ }^{34} \mathrm{Cf}$. Torquato Tasso, „Discorsi dell'arte poetica”, in Władysław Tatarkiewicz, Historia estetyki, vol. 3,184 .

${ }^{35}$ Władysław Tatarkiewicz, „Postawa estetyczna, literacka i poetycka”, in idem, Droga przez estetykę (Warszawa: Państwowe Wydawnictwo Naukowe, 1972), 84.

${ }^{36}$ Maciej Kazimierz Sarbiewski, O poezji doskonatej, 192. 
do drugiego" 37 , to w podobieństwie, będącym zestawieniem dwu obrazów, taka pedantyczna symetria odpowiedniości nie zachodzi. Tu raczej liczy się jakiś istotny rys, zauważalny często na poziomie mniej istotnych detali budujących specyficzną aurę emocjonalną, nierzadko decydującą o wymowie całości. Dzieje się tak, ponieważ - jak przekonuje poeta - dzięki Boskiej inwencji rzeczy istniejące w świecie pozostają w nieustającym odniesieniu do siebie i umysł przygotowany do dostrzeżenia tych odniesień przez erudycję (eruditio sufficiens) i odpowiednie ćwiczenia logiczne („,różnorodne ćwiczenie w układaniu proporcji między rzeczami, które są sobie podobne" ${ }^{38}$ ) staje się dla całości rzeczy widzialnych niejako zwierciadłem, w którym odsłaniają się ich istotne relacje ${ }^{39}$.

Przykładami praktycznego zastosowania tych prawidłowości do wykładu alegorycznych sensów heroicum są Alegoria poematu Torquata Tassa i 10 rozdział VI księgi De perfecta poesi, przedstawiające treści - odpowiednio - Jerozolimy wyzwolonej i Eneidy, odczytane w świetle filozofii moralnej - nauki życia szczęśliwego. Drobiazgowość tych eksplikacji może nieco przytłaczać współczesnego odbiorcę, ale to nie ona decyduje o właściwym charakterze lektury głębokiej, której mechanizm demonstruje Tasso, ale przede wszystkim - Sarbiewski. Mechanizm ten, choćby i pedantycznie, po szkolarsku opisany, uruchamia w umyśle czytelnika sama natura poesis perfecta - we wszystkich jej realizacjach, nie wyłączając dzisiejszych - oraz wejście w obszar oddziaływania poetyckiego piękna.

Alegoryczna potencjalność sprawia, że opowieść heroiczna staje się żywą konkretyzacją piękna moralnego, formując człowieka, jego osobowość i postawy przez specyficzne dla sztuki oddziaływanie „długodystansowe” czy „głębokie” - jak naturę wpływu silnego przeżycia estetycznego określiła niegdyś Maria Gołaszewska:

Wydaje się - pisała uczona - że im silniejszy, bardziej sprecyzowany i sugestywny jest wzór wyłaniający się z dzieła sztuki, tym bardziej skuteczny jest on w oddziaływaniu doraźnym, tym mniej podatny na oddziaływania „głębokie”. Dziś szansa głębokiego oddziaływania sztuki zachodzi wtedy, gdy przedstawiony w niej model człowieka rysuje się jako możliwość, którą odbiorca musi samodzielnie dookreślić i odnieść do własnego życia ${ }^{40}$.

Wydaje się, że u podstaw takiego rozróżnienia między formami literackiego oddziaływania leży rozpoznanie podobne do tego, które poprowadziło Sarbiewskiego do wskazania różnicy między odmiennymi celami (a przez to i skutkami) „prostego naśladowania bohatera” (simplex imitatio herois) a tymi, które właściwe

${ }^{37}$ Idem, „De figuris sententiarum. O figurach myśli”, in idem, Wyktady poetyki (Praecepta poetica), trans. et ed. Stanisław Skimina (Wrocław - Kraków: Zakład Narodowy im. Ossolińskich et Wydawnictwo PAN, 1958), 200.

${ }^{38}$ Ibidem.

${ }^{39}$ Ibidem, 201.

${ }^{40}$ Maria Gołaszewska, „Wzory moralne a sztuka”, Etyka, no. 17 (1979), 51. 
są „sumie wiadomości wykładanych pośrednio” (encyclopaedia obliqua $)^{41}$. Centralną postacią eposu jest wódz i władca, zatem tylko książęta i królowie mogą być adresatami bezpośredniego pouczenia płynącego z kreacji epickiego protagonisty. Oni jedni mogą skorzystać $\mathrm{w}$ sensie dosłownym - a więc i doraźnie - z nauki przywracania sprawiedliwego ładu wśród ludu, z wzorów monarszych cnót i wspaniałomyślnego panowania, czego przykłady ukazują poszczególne wydarzenia akcji epickiej. Tymczasem, jak czytamy w De perfecta poesi:

przy pomocy wiadomości podawanych pośrednio lub raczej dzięki fabule, ale nie rozumianej w sensie dosłownym, lecz pośrednim, bezpośrednio i w pierwszym rzędzie każdy człowiek otrzymuje pełnię wiadomości, jak żyć dobrze i szczęśliwie, ponieważ pokazuje mu się alegorycznie bądź to wszystkie środki do osiągnięcia szczęśliwości, bądź też określone drogi do jakiejś jej częścici ${ }^{42}$.

Alegoryczny poziom znaczeń poematu epickiego integruje jego wymiar przyjemnościowy i dydaktyczny. To tu właśnie dokonuje się synteza mimetycznej bezinteresowności z celowością moralną właściwą wszystkim aktom specyficznie ludzkim, także twórczości poetyckiej - choćby i była zrodzona z impulsów ludycznych. Istotnym początkiem alegorycznej lektury epiki heroicznej okazuje się raczej dostrzeganie znaczeń przenośnych niż ich poszukiwanie. W trakcie czytania odbiorca doświadcza tego, iż nie tyle ma przed sobą wzniosłe egzemplum uniwersalnych procesów i poetę piszącego o fundamentalnych zasadach życia, ile że zasady te ukazują się w swojej aktywności samoczynnie poprzez kreację autorskiej imaginatio ${ }^{43}$. Myślenie o alegorii jako formie, w której dzieło znajduje swoje ostateczne uzasadnienie i zupełny kształt, jest nierozdzielnie związane $\mathrm{z}$ zagadnieniem wyobraźni poetyckiej.

\section{ALLEGORY AS A CONDITION OF EPIC EXCELLENCE}

\section{Sum mary}

This article concerns the potential of figurative meaning in heroic poems as well as the links between epic mimesis and allegorical interpretation. It also deals with an early modern idea of a literary masterpiece and its standards. As an outstanding work, a poem should be attractive for both trained and less advanced readers, those who are capable to grasp intellectually each level of the text, and those who simply want to enjoy poetry as a source of pleasure and otium. The analysis of Alegoria del poema by Torquato Tasso and De perfecta poesi by Maciej Kazimierz Sarbiewski proves that in the early modern period the idea of figurative meaning of epic poems was still widely

${ }^{41}$ Cf. Maciej Kazimierz Sarbiewski, O poezji doskonałej, 190-191.

${ }^{42}$ Ibidem, 191.

${ }^{43}$ Cf. Clive Staples Lewis, The Allegory of Love. A Study of Medieval Tradition (New York: Oxford University Press, 1958 [1960]), 358. 
recognized. This multidimensional semantic structure, conceptualized by writers and critics, combines both didactic and the 'pleasure-giving' aspect of a poem as well as makes the epic plot a vivid actualization of moral beauty, and thus influences a reader in a long-lasting way typical of poetry and art. An allegorical interpretation, built over a structure of a heroic fable, unites the sensual beauty of things with an intellectual experience of the great order of the world. It also adds universal qualities to the mimesis of a poem and opens it up to a cognitive and ethical perspective. The process of intense reading, although described in academic terms in Renaissance and Baroque literary criticism, is initiated in a reader's mind, as (s)he gets exposed to poetic beauty by the very nature of poesis perfecta. 